\title{
Interactive effects of shading and proximity to the seafloor on the development of subtidal epibiotic assemblages
}

\author{
T. M. Glasby* \\ Centre for Research on Ecological Impacts of Coastal Cities, Marine Ecology Laboratories, A11, University of Sydney, \\ New South Wales 2006, Australia
}

\begin{abstract}
A manipulative experiment was done to test hypotheses about the interactive effects of shading and proximity to the seafloor on the development of subtidal epibiotic assemblages. It was proposed that differences in these 2 factors could explain differences described previously between assemblages of sessile organisms on rocky reefs and pier pilings in estuaries. Sandstone settlement plates were deployed in 2 positions (close to and far from the seafloor) and sets of plates were experimentally shaded in each position. Effects of shading and proximity to the seafloor were apparent after $1.2 \mathrm{wk}$ and many persisted for all $33 \mathrm{wk}$ of the experiment. Largest differences in assemblages were due to position relative to the seafloor (which greatly affected the cover of spirorbid polychaetes, barnacles, bryozoans and sponges) and there was a significant multivariate effect of shading on assemblages close to the seafloor Shading influenced the cover of colonial ascidians, algae and cyanobacteria in both positions, but many other taxa in only 1 position. Possible reasons for these differences are discussed. Results suggested that differences in assemblages between rocky reefs and pilings could largely be due to differences in shading and proximity to the seafloor.
\end{abstract}

KEY WORDS: Sessile organisms - Fouling - Shade - Urban structures - Artificial habitats - Marinas . Environmental impact

\section{INTRODUCTION}

Urbanization of the coastal zone has resulted in numerous structures being added to the marine environment. Most of these are quite different from natural hard substrata in many ways, including their composition, position relative to the seafloor and the degree to which they are shaded. Pilings, for example, may be constructed of wood, concrete, steel or plastic and can provide shaded surfaces at a variety of depths and distances from the seafloor. Pontoons are floating structures constructed of concrete or fibreglass and are often situated many metres from the seafloor. It has been suggested that the addition of urban structures to waterways could affect the distribution and abundances of sessile biota (Karlson 1978, Glasby \& Connell 1999), and there is recent evidence that these struc-

•E-mail: tglasby@bio.usyd.edu.au tures create novel habitats in estuarine environments, with quite distinct assemblages of sessile organisms compared to those on natural rocky reefs (Connell \& Glasby 1999).

Assemblages on rocks in sheltered estuaries are covered primarily by algae and spirorbid polychaetes whereas nearby pilings tend to be dominated by serpulid polychaetes, sponges, solitary ascidians and species of encrusting bryozoans (Connell \& Glasby 1999 , Glasby 1999a). Many of these latter organisms also dominate pier pilings in other places (Karlson 1978, Kay \& Keough 1981, Kay \& Butler 1983, Butler 1986. 1991, Butler \& Connolly 1996). Moreover, differences between assemblages on pilings and rocks are comparable to those between pilings and the shells of the large bivalve Pinna bicolor (Butler 1991). Thus, it is possible that pilings have intrinsic properties which make them different habitats from natural hard substrata. 
Differences between assemblages on pilings and rocks could be due to a variety of factors and combinations of influences. Studies of effects of the composition of the substratum on epifauna have indicated that some species may recruit in very different abundances on different surfaces (e.g. Crisp \& Ryland 1960, Harlin \& Lindbergh 1977, McGuinness 1989, Anderson \& Underwood 1994), while others may not (e.g. Pomerat \& Weiss 1946, Crisp \& Ryland 1960, Caffey 1982, Anderson \& Underwood 1994). The taxa that often dominate wooden pilings have, however, also been found in large numbers on other surfaces, such as fibreglass, plastic and concrete (Connell \& Glasby 1999). It, therefore, seems likely that factors other than the composition of the substratum are important in determining the types of fouling organisms that become established on these different surfaces.

Shading can greatly affect the composition of epibiotic assemblages (e.g. Kennelly 1989, Duggins et al. 1990) and different degrees of shading are likely to explain some of the differences in the covers of epibiota on pilings and rocks (Glasby 1999b). Furthermore, there is evidence that epifaunal species dominating settlement plates on floating rafts are different from those on plates attached to the seafloor (Fuller 1946, Withers \& Thorp 1977). Such differences could be due to the floating versus fixed nature of surfaces, depth and/or proximity to the seafloor. The limited data available on the behaviour of planktonic larvae indicate that some species of polychaetes become more demersal as they develop (Smith 1984, Scheltema 1986) and, thus, could be expected to settle in greatest numbers on substrata close to the seafloor. Many biotic and abiotic factors vary with proximity to the seafloor, so it is likely that different assemblages of organisms would occur on substrata in different positions relative to the seafloor (e.g. Long \& Rucker 1970 , Glasby unpubl. data).

Given that pier pilings are typically situated in deep water, samples taken at a shallow depth (e.g. $1.5 \mathrm{~m}$ as in Glasby 1999a) would be many metres from the seafloor. Samples taken at the same depth on gentlysloping rocky reefs would, however, generally be within centimetres of the seafloor. Differences in the proximity to the seafloor could, therefore, explain differences between epibiotic assemblages on pilings and rocky reefs. However, pilings also tend to be 10 to $20 \mathrm{~m}$ further from the shore than rocky reefs and there is evidence that this may influence the composition of assemblages on these 2 surfaces (Glasby unpubl. data).

The purpose of this study was to experimentally test hypotheses about the interactive effects of proximity to the seafloor and shading on the development of subtidal epibiotic assemblages without confounding effects of proximity to the shore. This required a comparison of shaded and unshaded assemblages close to and far from the seafloor which were all similar distances from the shore. The main predictions were that (1) unshaded assemblages close to the seafloor would be qualitatively similar to those sampled previously on rocky reefs (i.e. dominated by the same taxa) and (2) shaded assemblages far from the seafloor would be qualitatively similar to those sampled previously on shaded pilings.

\section{MATERIALS AND METHODS}

Development of assemblages on settlement plates. The experiment was done at the Royal Volunteer Coastal Patrol in Middle Harbour, a sheltered embayment in the northern part of Sydney Harbour, Australia. The substratum in this area consists primarily of sandy soft sediments, small patches of seagrass (Zostera capricorni and Posidonia australis), pilings and a few concrete mooring blocks. There was no rocky reef within $500 \mathrm{~m}$ of the experimental area. Sandstone settlement plates $(15 \times 15 \mathrm{~cm}$; Glasby 1998) positioned vertically were used to study the establishment of epibiotic assemblages. All plates had been used previously (i.e. had been under water for at least $10 \mathrm{mo}$ ) and had been cleaned in $20 \% \mathrm{HCl}$, soaked in fresh water and dried. Plates were deployed at a depth of $1.8 \mathrm{~m}$ below Mean Low Water Springs in September 1997 (Spring) and were submerged for $33 \mathrm{wk}$.

Four replicate plates were placed in each of 3 shading treatments (shaded, procedural control, full control; see below) in each of 2 positions relative to the seafloor (close to and far from the seafloor). The plates positioned close to the seafloor (within $20 \mathrm{~cm}$ ) were attached to aluminium beams $(32 \times 32 \mathrm{~mm}$ aluminium $90^{\circ}$ angle) that were screwed onto concrete blocks which sat on the sandy substratum. PVC brackets were glued onto the backs of plates and these were bolted to the side of the aluminium angle (Glasby 1998). The plates were vertical, faced north (away from the shore) and were $\sim 25 \mathrm{~m}$ from the shore. They were situated in areas not shaded by boats or pontoons, but most were within a few metres of established epibiotic assemblages on pilings and mooring blocks. The extent to which these assemblages may have influenced settlement on the experimental plates is not known. Plates were arranged randomly such that any 2 replicates were spaced between $50 \mathrm{~cm}$ and $10 \mathrm{~m}$ apart. Four replicate plates were shaded by opaque black Perspex roofs which were attached $\sim 20 \mathrm{~cm}$ above the plates. Another 4 plates served as procedural controls, i.e. they had clear Perspex roofs above them (which had all the features of the shaded 
treatment, except the shade itself, and so tested for any artefacts associated with the roof structure). Silt and attached organisms were cleaned from the tops and undersides of the clear and black roofs every $10 \mathrm{~d}$ using a scrubbing brush. Plates that served as full controls had no roofs above them.

Another set of plates was attached to free-standing pilings (not shaded by boats etc.) which were $\sim 6 \mathrm{~m}$ seaward of the plates close to the seafloor. These plates also faced north, but were $-3 \mathrm{~m}$ from the seafloor. Plates were attached to aluminium beams clamped on to the pilings (as described in Glasby 1999b) and so were $\sim 50 \mathrm{~cm}$ from established assemblages growing on the pilings. Note, however, that assemblages on the various pilings used in the experiment appeared very different, probably because they were different ages (1 to 10 yr old). Replicates were spaced at similar distances to those that were close to the seafloor and were allocated to the same 3 shading treatments. Black and clear Perspex roofs were attached to pilings above plates (Glasby 1999b) so that they formed structures very similar to those above the plates placed close to the substratum.

The fronts of plates were photographed in situ after $12 \mathrm{wk}$ using a Nikonos IV with a $35 \mathrm{~mm}$ lens, a $30 \mathrm{~cm}$ diopter and a strobe. Slides were sampled by projecting the image on to a screen and estimating percentage covers of taxa using a $13 \times 13 \mathrm{~cm}$ grid of $100 \mathrm{regu}-$ larly spaced points. After $33 \mathrm{wk}$, the plates were collected, suspended and supported in tubs of seawater for transport back to the laboratory where they were transferred into filtered $(10 \mu \mathrm{m}$ filter) seawater and refrigerated at $5^{\circ} \mathrm{C}$ until sorted (within $5 \mathrm{~d}$ of collection) under a dissecting microscope. Primary cover (organisms attached directly to the plate) and secondary cover (organisms attached to primary cover) were estimated for taxa on the fronts of plates using the same grid sampling technique used for the photographs. Direct comparisons of patterns between the 12 and 33 wk samples were not made because different methods of sampling were used, but it was assumed that the relative differences among treatments should be comparable for the 2 times of sampling.

Light intensity. On 2 occasions (April, May), quantity of light (photosynthetically active radiation) was recorded next to each of the plates (i.e. in the 2 positions relative to the seafloor and in each of the 3 shading treatments). A Li-Cor UW quantum sensor (held horizontally, facing away from the front of the settlement plate) was used in combination with a LI-1000 integrating quantum photometer. Light intensity was measured under the clear Perspex roofs before and after being cleaned of sediment and attached organisms.
Estimates of sedimentation. Experimental reductions in sedimentation have been found to influence the development of subtidal algal assemblages on horizontal surfaces (Airoldi \& Cinelli 1997) and these reductions have been achieved using clear plastic roofs. Thus, it was possible in the present study that assemblages on plates under the clear Perspex roofs (i.e. the procedural controls) could develop differently from those with no roofs (i.e. full controls) because of reduced sedimentation in the former treatment. To test the prediction that rates of sedimentation would be reduced by the roofs, sediment traps $(16 \mathrm{~cm}$ tall plastic cylinders with a diameter of $5 \mathrm{~cm}$ ) were attached vertically to the aluminium beams adjacent to the settlement plates $(\sim 15 \mathrm{~cm}$ away) in each of the procedural control (clear roof) and full control (no roof) treatments in both positions. Sedimentation under the black roofs was assumed to be similar to that under the clear roofs, but 'dummy' traps were placed under the black roofs whenever sedimentation was being estimated for other treatments (in case the traps altered patterns of water flow around the settlement plates). $10 \mathrm{ml}$ of $5 \%$ formaldehyde solution were added to each sediment trap to prevent decomposition of organic material.

Sedimentation was estimated 4 times over the course of the experiment (November, December, February, April). Each time, traps were left in situ for 7 to $10 \mathrm{~d}$. When collecting traps, they were sealed with a lid and placed individually into plastic bags. In the lab, each sample was filtered first through a $200 \mu \mathrm{m}$ mesh (coarse fraction), then through a pre-weighed (dried at $70^{\circ} \mathrm{C}$ ) Whatman GF/B $1 \mu \mathrm{m}$ filter paper (fine fraction) using distilled water. Coarse and fine fractions were then dried at $70^{\circ} \mathrm{C}$ to a constant weight.

Water movement. Preliminary results indicated that there were large differences between assemblages on settlement plates close to and those far from the seafloor. A possible explanation for this was that there were differences between the 2 positions in water movement. Thus, immediately after the completion of the settlement study (i.e. autumn 1998), plaster clod cards (Doty 1971, Jokiel \& Morrissey 1993) were used to test whether any such differences existed between the 2 positions. Clods were made from plaster of Paris and were hemispherical with a base diameter of $6 \mathrm{~cm}$ and a height of $2 \mathrm{~cm}$ (dry weight $45 \pm 4 \mathrm{~g}$ ). Care was taken to remove bubbles from the mixture whilst drying. Weight loss of plaster clods in still seawater in the laboratory was found to be linear over $5 \mathrm{~d}$, with an average loss of $1.5 \mathrm{~g} \mathrm{~d}^{-1}$. Clods were glued to Perspex cards, soaked in seawater for $24 \mathrm{~h}$, rinsed with fresh water, blotted dry and weighed (Jokiel \& Morrissey 1993). They were then clipped to the fronts of settlement plates (no longer being used for the settlement experiment) close to the seafloor and far from the 


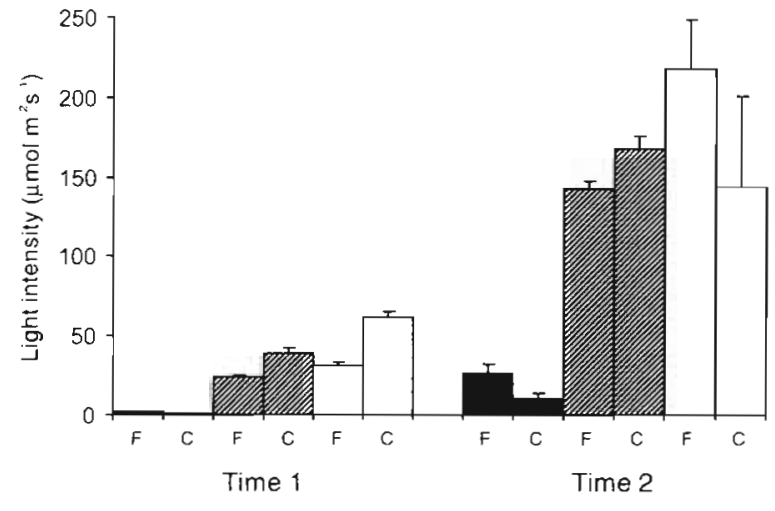

Fig. 1. Mean (+ SE) light intensities measured near settlement plates in different shading treatments (shaded $=\mathbf{0}$, procedural control $=$, full control $=\square$ ) in each position (far from $[F]$ and close to $[C]$ the seafloor). Values for procedural controls (clear roof) are averages of measurements taken under roofs that had not been cleaned of sediment for $7 \mathrm{~d}$ and the same roofs immediately after cleaning

seafloor and left in situ for $3 \mathrm{~d}$. In the lab, the cards were rinsed with freshwater, blotted dry and weighed. Sets of clod cards were deployed on 4 occasions.

Statistical analyses. Percentage cover estimates of sessile organisms on plates for each time of sampling were analysed (using ANOVA and the multivariate package PRIMER) separately to avoid problems of nonindependence. Univariate data were not transformed unless variances were heterogeneous (Cochran's $C$ test, $\alpha=0.05$ ) in which case they were transformed to arc-sine. Multivariate data were fourth-root transformed and Bray-Curtis similarity matrices calculated. One-way analyses of similarities (ANOSIM; Clarke \& Green 1988) and multiple pairwise comparisons tested for differences in assemblages among treatments. For the 33 wk samples, data for primary and secondary covers of each taxon were combined and expressed as a percentage for univariate and multivariate analyses.

\section{RESULTS}

\section{Light intensity}

Black perspex roofs reduced the amount of light reaching the settlement plates by $\sim 90$ to $95 \%$ relative to the uncovered plates, whereas clear roofs reduced light levels by only $\sim 25$ to $30 \%$ (Fig. 1). In both positions and at each time of sampling, there was significantly less light in shaded treatments than in the procedural control or full control treatments (Table 1). For the second sample, however, there was significantly more light in positions far from the seafloor than close to the seafloor (Table 1, Fig. 1); $25.8 \pm 6.1 \mu \mathrm{mol} \mathrm{m}{ }^{-2} \mathrm{~s}^{-1}$ (mean $\pm \mathrm{SE}$ ) of light reached the shaded plates far from the seafloor compared to $10.5 \pm 2.7 \mu \mathrm{mol} \mathrm{m}^{-2} \mathrm{~s}^{-1}$ of light adjacent to the shaded plates close to the seafloor (Fig. 1). A similar magnitude of difference occurred for the first sample, when $2.0 \pm 0.5 \mu \mathrm{mol} \mathrm{m} \mathrm{m}^{-2} \mathrm{~s}^{-1}$ reached shaded plates far from the seafloor whereas only $1.2 \pm 0.1 \mu \mathrm{mol} \mathrm{m}^{-2} \mathrm{~s}^{-1}$ of light reached shaded plates close to the seafloor.

\section{Assemblages on settlement plates}

Multivariate analyses compared the percentage covers of 47 taxa (including polychaetes, bryozoans, barnacles, hydroids, algae, cyanobacteria, diatoms, coral, sponges and ascidians) and bare space on plates. As predicted, there was a clear multivariate effect of shading after $12 \mathrm{wk}$, i.e. in both positions, assemblages that were shaded were significantly different from those in the procedural control and full control treatments (Table 2a). There were also significant multivariate differences for all pairwise comparisons between assemblages far from and close to the seafloor, again consistent with the predictions (Table 2a). The difference between shaded and unshaded assemblages far from the seafloor was less obvious after $33 \mathrm{wk}$ and pairwise comparisons did not detect any significant differences in this position (Table 2b).

Table 1. Comparison of light intensities in the 3 shading treatments in each position, measured on 2 occasions. Data were transformed to natural logarithms and variances were heterogeneous (Cochran's $C=0.466, p<0.01$ ). Time was a random factor, Position and Shading were fixed. ns: $p>0.05 ; p<0.05, \cdots p<0.01, \cdots p<0.001$. =: no significant difference, $p>0.05$. Sh $=$ shaded, $\mathrm{PC}=$ procedural control, $\mathrm{C}=$ full control

\begin{tabular}{|c|c|c|c|c|c|c|}
\hline Source & df & MS & $F$ & $\mathrm{p}$ & \multicolumn{2}{|c|}{ Relevant SNK tests } \\
\hline Time & 1 & 35.63 & 216.14 & $\cdots$ & & \\
\hline Position & 1 & 0.16 & 0.10 & $\mathrm{~ns}$ & & \\
\hline Shading & 2 & 40.84 & 34.81 & $\cdot$ & & \\
\hline $\mathrm{T} \times \mathrm{P}$ & 1 & 1.63 & 9.92 & $\cdots$ & Time 1. Far = Close & Time 2: Far > Close \\
\hline $\mathrm{T} \times \mathrm{Sh}$ & 2 & 1.17 & 7.12 & 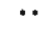 & Time 1: $\mathrm{Sh}<\mathrm{PC}=\mathrm{C}$ & Time 2: $\mathrm{Sh}<\mathrm{PC}=\mathrm{C}$ \\
\hline $\mathrm{P} \times \mathrm{Sh}$ & 2 & 1.00 & 3.18 & ns & & \\
\hline $\mathrm{T} \times \mathrm{P} \times \mathrm{Sh}$ & 2 & 0.31 & 1.90 & $\mathrm{~ns}$ & & \\
\hline Residual & 36 & 0.16 & & & & \\
\hline
\end{tabular}


Table 2. Bray-Curtis dissimilarity percentages for pairwise comparisons of assemblages on plates positioned far from (F) and close to (C) the seafloor in different shading treatments $(\mathrm{Sh}=$ shaded, $\mathrm{PC}=$ procedural control, $\mathrm{C}=$ full control) after (a) $12 \mathrm{wk}$ and (b) $33 \mathrm{wk}$. Note that both the PC and C treatments are unshaded. Plates were sampled photographically after $12 \mathrm{wk}$ and microscopically after $33 \mathrm{wk}$. Data were fourth-root transformed. $p<0.05$ (ANOSIM)

\begin{tabular}{|lccccc|}
\hline (a) 12 wk & & & & & \\
F PC & $38.3^{\circ}$ & & & & \\
F C & $46.5^{\circ}$ & 24.6 & & & \\
C Sh & $44.8^{\circ}$ & $38.5^{\circ}$ & $40.2^{\circ}$ & & \\
C PC & $54.7^{\circ}$ & $27.7^{\circ}$ & $31.0^{\circ}$ & $40.0^{\circ}$ & \\
C C & $52.3^{\circ}$ & $26.4^{\circ}$ & $29.7^{\circ}$ & $39.0^{\circ}$ & 13.4 \\
& F Sh & F PC & FC & C Sh & C PC \\
& & & & & \\
(b) 33 wk & & & & & \\
F PC & 27.8 & & & & \\
F C & 32.4 & $27.5^{\circ}$ & & & \\
C Sh & $40.0^{\circ}$ & $39.7^{\circ}$ & $41.5^{\circ}$ & & \\
C PC & $49.9^{\circ}$ & $41.9^{\circ}$ & $40.5^{\circ}$ & $39.9^{\circ}$ & \\
C C & $47.3^{\circ}$ & $41.1^{\circ}$ & $39.2^{\circ}$ & $40.5^{\circ}$ & 27.6 \\
& F Sh & F PC & F C & C Sh & C PC \\
\hline
\end{tabular}

Shaded and unshaded assemblages close to the seafloor continued to be significantly different throughout the experiment and, overall, assemblages far from the seafloor were always different from those close to the seafloor (Table 2b, Fig. 2).

Without a formal test for a multivariate interaction (which is not yet available), it is difficult to interpret the results of these pairwise comparisons, i.e. it is not clear if these a posterion pairwise comparisons are warranted unless a multivariate test for a Position $\times$ Shading interaction is done. Nevertheless, by $33 \mathrm{wk}$ the multivariate differences between shaded and unshaded assemblages positioned far from the seafloor were less than the corresponding differences close to the seafloor (Fig. 2, Table 2b).

Differences in the total numbers of animals occurred among shading treatments and between plates in the 2 positions. There were significantly more animals on shaded than unshaded plates in newly established assemblages after 12 wk (Fig. 3a), but differences between positions were not consistent among shading treatments (Table 3). By $33 \mathrm{wk}$, there were significantly more animals on plates far from the seafloor and more on shaded than unshaded plates in both positions (Table 4a, Fig. 4a).

Patterns for individual taxa were quite varied. After 12 wk, there were significantly more spirorbid polychaetes on shaded than unshaded plates close to the seafloor and more spirorbids on plates close to the seafloor than on plates far from the seafloor (Table 3 , Fig. 3b). The marked difference between plates in the 2 positions persisted until the end of the experiment
(Table 4 b, Fig. 4 b), but the positive influence of shading seemed to have disappeared by $33 \mathrm{wk}$ (Table $4 \mathrm{~b}$ ). In fact, after $33 \mathrm{wk}$, spirorbids tended to be less common on shaded than unshaded plates far from the seafloor (Fig. 4b). Serpulid polychaetes Hydroides elegans and $H$. ezoensis were also affected by shading, but again, only on plates close to the seafloor. After 12 and 33 wk more Hydroides spp. occurred on shaded plates close to the seafloor than on other plates (Tables $3 \& 4 c$, Figs. 3c \& 4c).

In newly developing assemblages, the barnacle Balanus trigonus was significantly more abundant on shaded than unshaded plates (Table 3, Fig. 3d). By 33 wk, there was no significant effect of shading, but there were significantly more $B$. trigonus close to than far from the seafloor at this time (Table $4 \mathrm{~d}$. Fig. $4 \mathrm{~d}$ ). The opposite pattern occurred for Watersipora subtorquata, which was most abundant far from the seafloor after 12 and 33 wk (Tables 3 \& 4d, Figs. 3e \& 4e). Another bryozoan, Schizoporella errata, was not common on plates until the assemblages were well developed, after which time it was significantly more abundant on plates far from the seafloor than close to the seafloor (Table 4f, Fig. 4f).

Solitary ascidians were rare on plates for the first 7 mo of the experiment. By $33 \mathrm{wk}$, solitary ascidians tended to be most abundant on shaded plates that were far from the seafloor (Fig. $4 \mathrm{~g}$ ), although this difference was not significant (Table $4 \mathrm{~g}$ ). Similarly, colonial ascidians were rare until the end of the experiment when they were significantly more abundant on shaded than unshaded plates in both positions (Table 4h, Fig. 4h). Patterns for sponges varied

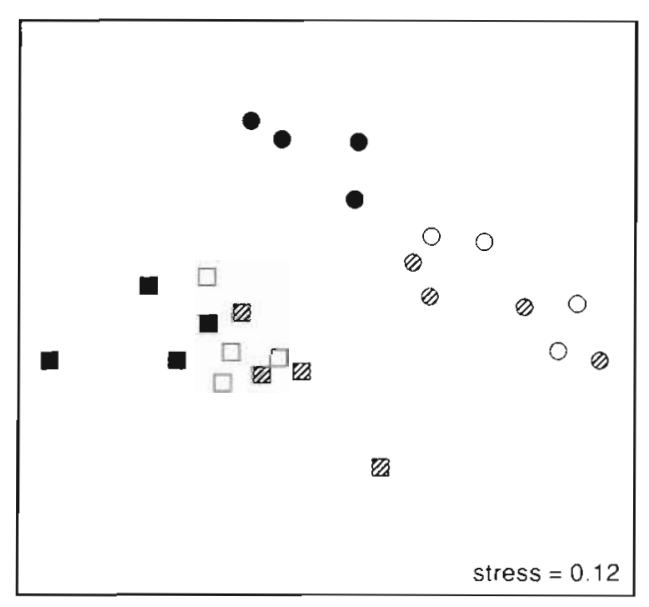

Fig. 2. Non-metric multidimensional scaling ordination of assemblages on settlement plates positioned close to the seafloor (circles) and far from the seafloor (squares) in each of 3 shading treatments (shaded $=\mathbf{\square}$, procedural control $=\mathbb{Z}$. full control $=\square$ ) after $33 \mathrm{wk} ; \mathrm{n}=4$ replicates 
(a) Total animals
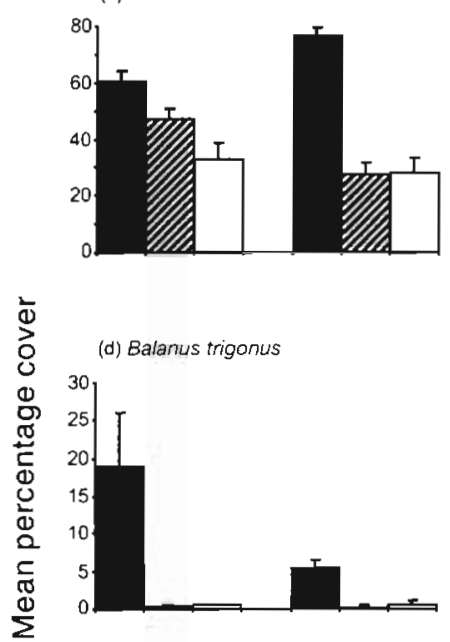

(8) Total aigae

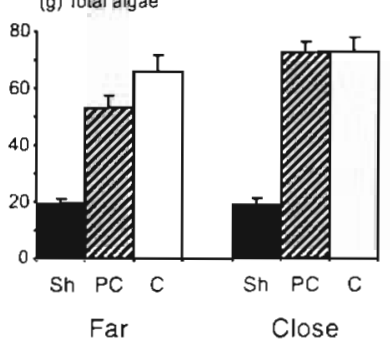

(b) Spirorbids

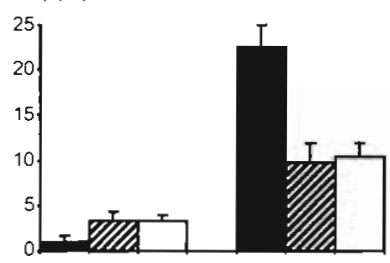

(e) Watersipora subtorquata

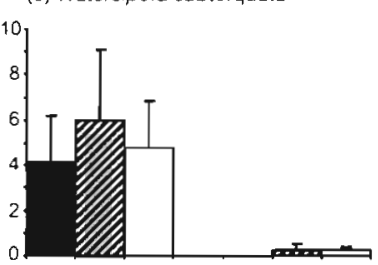

(h) Filamentous

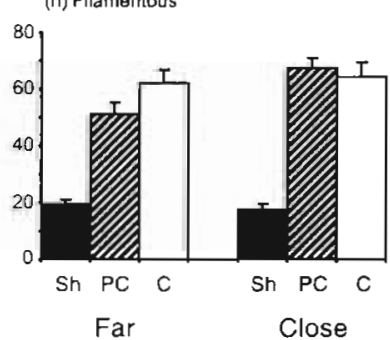

(c) Hydroides spp

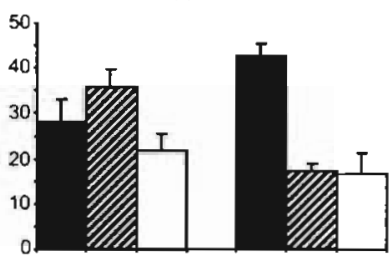

(1) Sponges
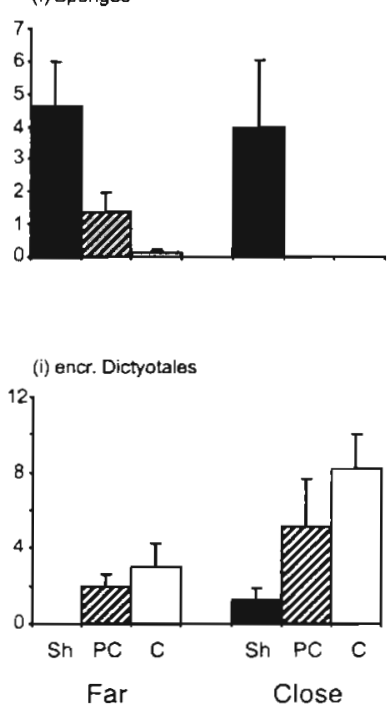

Fig. 3. Covers (+ SE) of taxa on settlement plates in the 3 shading treatments (shaded, procedural control, full control) in each of 2 positions (far from and close to the seafloor) after $12 \mathrm{wk}$

between samples. The cover of sponges was greatest on shaded plates after 12 wk (Table 3, Fig. 3f). By $33 \mathrm{wk}$, the effect of shading was no longer apparent, instead the cover of sponges was greatest on plates far from the seafloor (Table 4i, Fig. 4i).

After $12 \mathrm{wk}$, algae were uncommon on shaded plates and less abundant on plates far from the seafloor than on plates close to the seafloor (Table 3, Fig. 3g). By $33 \mathrm{wk}$, shaded plates had a reduced cover of algae, but this was only significant for plates close to the seafloor (Table 4j, Fig. 4j). On unshaded plates, algae were significantly more abundant close to than far from the seafloor (Table 4j, Fig. 4j), while shading apparently caused the cover of algae to be similar in the 2 positions (Fig. 4j).

Some small taxa were, undoubtedly, either missed in photographic samples or lumped together (with taxa such as filamentous algae and the cyanobacterium Oscillatoria sp.) into the group 'filamentous'. The cover of filamentous organisms was significantly less on shaded than unshaded plates after 12 wk (Table 3 , Fig. 3h) and the same pattern occurred for Oscillatoria sp. after 33 wk (Table 4k, Fig, 4k). Red filamentous algae (ceramialean algae including Polysiphonia sp. and Antithamnionella spp.) tended to be less abundant on shaded than unshaded plates, but this difference was only significant for plates close to the seafloor (Table 4l, Fig. 4l). By the end of the experiment, the cover of ceramialean algae was greatest on plates in the 2 control treatments positioned close to the seafloor; again shading appeared to make the covers of these algae similar in the 2 positions (Fig. 4l). Encrusting dictyotalean algae were common on plates only after $12 \mathrm{wk}$, when their cover was greater on plates close to than on those far from the seafloor, and on unshaded than on shaded plates (Table 3, Fig. 3i).

\section{Effects of roofs and position on rates of sedimentation}

For both coarse and fine sediments, there was a significant interaction between treatment and time of sampling $(9,48 \mathrm{df} ; F=2.43, \mathrm{p}<0.05$ and $F=3.43, \mathrm{p}<$ 0.01 , respectively). SNK tests could not detect differences in amounts of coarse sediment among the 4 treatments, but there was a tendency for more to be collected in traps far from the seafloor and not covered 
Table 3. Summary of 2 -factor ANOVAs comparing taxa sampled photographically on plates after 12 wk. Position (far from the seafloor, close to the seafloor) and Shading (shaded, procedural control, control) were fixed factors; $\mathrm{n}=4$ replicates. If $\mathrm{P} \times \mathrm{S}$ was significant, only the SNK results for that interaction are presented. Inconsistent SNK results are noted. All data were untransformed except Balanus trigonus and encrusting Dictyotales which were transformed to arc-sine. Variances were homogeneous for all tests except $B$. trigonus and sponges. Statistical notation as in Table 1

\begin{tabular}{|c|c|c|c|c|c|c|}
\hline Taxon & Position & Shading & $\mathrm{P} \times \mathrm{Sh}$ & & Relevant SNK tests & \\
\hline Total animals & ns & $\cdots$ & $\cdots$ & $\begin{array}{c}\text { Far: } \mathrm{Sh}>\mathrm{PC}=\mathrm{Co} \\
\text { Sh: } \mathrm{F}<\mathrm{C}\end{array}$ & PC: $F>C$ & $\begin{array}{c}\text { Close: } \mathrm{Sh}>\mathrm{PC}=\mathrm{Co} \\
\mathrm{Co}: \mathrm{F}=\mathrm{C}\end{array}$ \\
\hline Spirorbids & $\cdots$ & $\cdots$ & $\cdots$ & $\begin{array}{c}\text { Far: } \mathrm{Sh}=\mathrm{PC}=\mathrm{Co} \\
\text { Sh: } \mathrm{F}<\mathrm{C}\end{array}$ & PC: $\mathrm{F}<\mathrm{C}$ & $\begin{array}{c}\text { Close: } \mathrm{Sh}>\mathrm{PC}=\mathrm{Co} \\
\mathrm{Co}: F<\mathrm{C}\end{array}$ \\
\hline Hydroides spp. & ns & $\because$ & $\because$ & $\begin{array}{l}\text { Far: inconsistent } \\
\text { Sh: } \mathrm{F}<\mathrm{C}\end{array}$ & $P C: F>C$ & $\begin{array}{c}\text { Close: } \mathrm{Sh}>\mathrm{PC}=\mathrm{Co} \\
\mathrm{Co}: \mathrm{F}=\mathrm{C}\end{array}$ \\
\hline Balanus trigonus & ns & $\cdots$ & ns & $\mathrm{Sh}>\mathrm{PC}=\mathrm{Co}_{0}$ & & \\
\hline Watersipora subtorquata & $\because$ & ns & ns & Far $>$ Close & & \\
\hline Sponges & ns & $\cdots$ & ns & $\mathrm{Sh}>\mathrm{PC}=\mathrm{Co}_{0}$ & & \\
\hline Total algae & $\cdot$ & $\cdots$ & ns & Far $<$ Close & $\mathrm{Sh}<\mathrm{PC}=\mathrm{Co}_{0}$ & \\
\hline Filamentous & ns & $\cdots$ & ns & $\mathrm{Sh}<\mathrm{PC}=\mathrm{Co}$ & & \\
\hline Encrust. Dictyotales & $\because$ & $\cdot \cdot$ & ns & Far $<$ Close & $\mathrm{Sh}<\mathrm{PC}=\mathrm{Co}$ & \\
\hline
\end{tabular}

Table 4. Comparisons of percentage covers of selected taxa on plates in 2 positions and 3 shading treatments after $33 \mathrm{wk} ; \mathrm{n}=4$ replicates. Data were transformed to arc-sine, except for (a), (b), (c), (e), (f) and (j), which were untransformed. Variances were homogeneous, $p>0.05$ for all tests except $(\mathrm{g})$ and $(\mathrm{l})$

\begin{tabular}{|c|c|c|c|c|c|c|c|}
\hline Source & $\mathrm{df}$ & MS & $F$ & $\mathrm{p}$ & MS & $F$ & $\mathrm{p}$ \\
\hline & & \multicolumn{3}{|c|}{ (a) Total animals } & \multicolumn{3}{|c|}{ (b) Spirorbids } \\
\hline Position & 1 & 1395.38 & 6.16 & $\cdot$ & 532.04 & 36.36 & $\cdots$ \\
\hline Shading & 2 & 994.77 & 4.39 & $\cdot$ & 8.26 & 0.56 & ns \\
\hline $\mathrm{P} \times \mathrm{Sh}$ & 2 & 517.51 & 2.28 & ns & 19.20 & 1.31 & ns \\
\hline \multirow[t]{2}{*}{ Residual } & 18 & 226.54 & & & 14.63 & & \\
\hline & & \multicolumn{3}{|c|}{ (c) Hydroides spp. } & \multicolumn{3}{|c|}{ (d) Balanus trigonus } \\
\hline Position & 1 & 133.01 & 5.79 & $\cdot$ & 168.56 & 6.23 & $\cdot$ \\
\hline Shading & 2 & 246.59 & 10.74 & $\cdots$ & 39.02 & 1.44 & $\mathrm{~ns}$ \\
\hline $\mathrm{P} \times \mathrm{Sh}$ & 2 & 108.89 & 4.74 & $\cdot$ & 12.56 & 0.46 & $\mathrm{~ns}$ \\
\hline \multirow[t]{2}{*}{ Residual } & 18 & 22.95 & & & 27.04 & & \\
\hline & & \multicolumn{3}{|c|}{ (e) Watersipora subtorquata } & \multicolumn{3}{|c|}{ (f) Schizoporella errata } \\
\hline Position & 1 & 15.04 & 5.68 & $\cdot$ & 1257.88 & 72.11 & $\cdots$ \\
\hline Shading & 2 & 10.86 & 4.10 & $\cdot$ & 10.94 & 0.63 & ns \\
\hline $\mathrm{P} \times \mathrm{Sh}$ & 2 & 2.39 & 0.90 & ns & 12.13 & 0.70 & ns \\
\hline \multirow[t]{2}{*}{ Residual } & 18 & 2.65 & & & 17.44 & & \\
\hline & & \multicolumn{3}{|c|}{ (g) Solitary ascidians } & \multicolumn{3}{|c|}{ (h) Colonial ascidians } \\
\hline Position & 1 & 17.05 & 2.31 & ns & 1.27 & 0.15 & ns \\
\hline Shading & 2 & 16.51 & 2.23 & ns & 40.89 & 5.00 & $\cdot$ \\
\hline $\mathrm{P} \times \mathrm{Sh}$ & 2 & 23.40 & 3.17 & ns & 4.03 & 0.49 & ns \\
\hline \multirow[t]{2}{*}{ Residual } & 18 & 7.39 & & & 8.18 & & \\
\hline & & \multicolumn{3}{|c|}{ (i) Sponge } & \multicolumn{3}{|c|}{ (j) Total algae } \\
\hline Position & 1 & 1865.54 & 94.18 & $\cdots$ & 2237.84 & 17.20 & $\cdots$ \\
\hline Shading & 2 & 27.00 & 1.36 & ns & 1524.80 & 11.72 & $\cdots$ \\
\hline $\mathrm{P} \times \mathrm{Sh}$ & 2 & 13.81 & 0.70 & ns & 606.10 & 4.66 & $\cdot$ \\
\hline \multirow[t]{2}{*}{ Residual } & 18 & 19.81 & & & 130.07 & & \\
\hline & & \multicolumn{3}{|c|}{ (k) Oscillatoria } & \multicolumn{3}{|c|}{ (1) Ceramiales } \\
\hline Position & 1 & 103.95 & 3.79 & ns & 633.88 & 25.55 & $\cdots$ \\
\hline Shading & 2 & 215.59 & 7.87 & $\cdot \cdot$ & 551.14 & 22.21 & $\cdots$ \\
\hline $\mathrm{P} \times \mathrm{Sh}$ & 2 & 24.74 & 0.90 & ns & 92.79 & 3.74 & $\cdot$ \\
\hline Residual & 18 & 27.40 & & & 24.81 & & \\
\hline
\end{tabular}


(a) Total animals

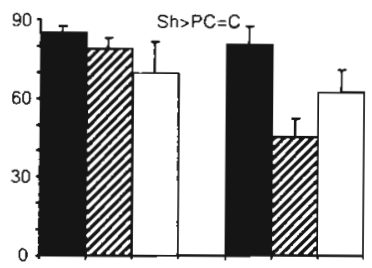

(d) Balanus trigonus

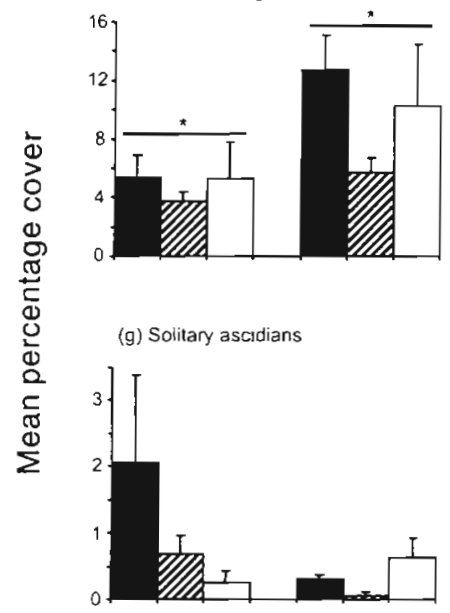

(j) Total algae

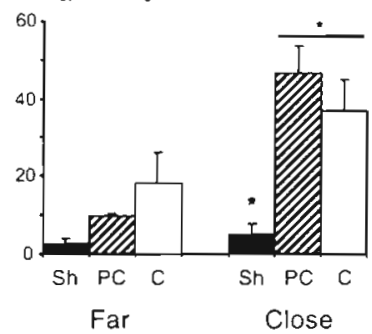

(b) Spirorbiơs

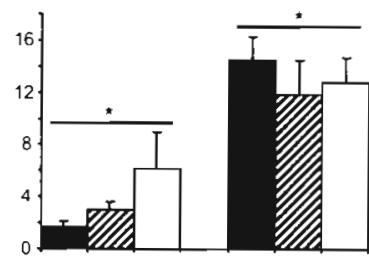

(e) Watersipora subtorquata

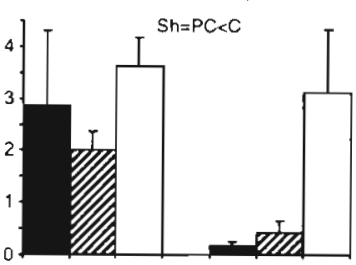

(h) Colonial ascidians

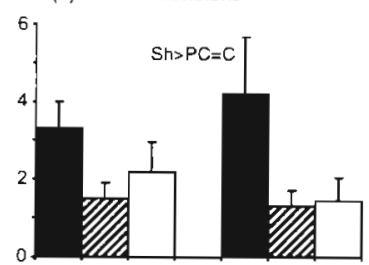

(k) Oscillatoria sp

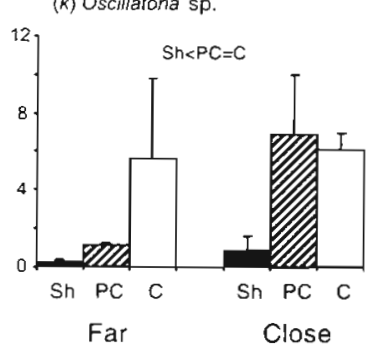

(c) Hydroides spp.

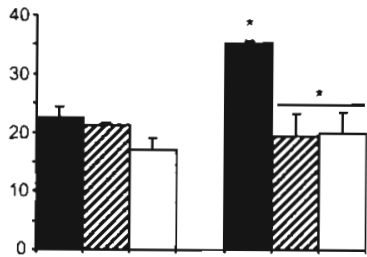

(f) Schizoporella errata

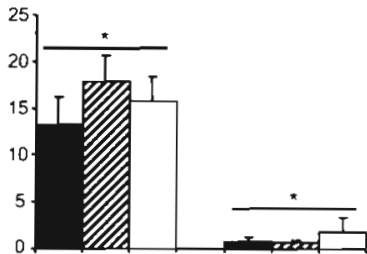

(i) Sponges

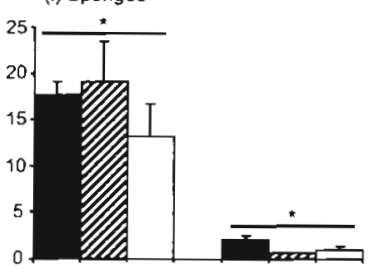

(l) Ceramiales

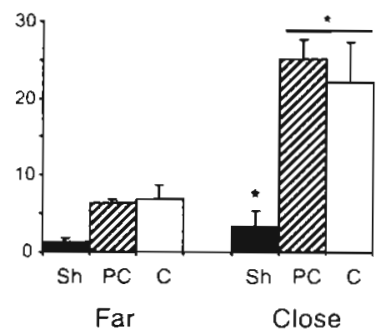

Fig. 4. Covers (+ SE) of taxa on settlement plates in the 3 shading treatments (shaded, procedural control, full control) in each of 2 positions (far from and close to the seafloor) after $33 \mathrm{wk}$. Bars cover treatments that are not significantly different (SNK test on means, $p>0.05$, pairs of asterisks indicate significant differences. Overall differences among shading treatments are written above graphs

by a roof for the first 2 times of sampling (Fig. 5a). The only significant difference identified by SNK tests for fine sediment was for the fourth sample, when there was more fine sediment collected in traps close to the seafloor than in traps far from the seafloor (Fig. 5b). A similar trend was apparent for the third sample (Fig. 5b). There was little indication that a roof significantly reduced the amount of fine sediment collected, but some evidence to suggest that the amount of coarse sediment may be reduced by roofs at some times, particularly in positions far from the seafloor. The most obvious result was the large temporal variability in sedimentation

\section{Comparisons of water flow between positions}

There were no consistent differences between positions in losses of weight of plaster clods among the 4 times of sampling. However, differences were only apparent between positions when, overall, there was the greatest loss of weight from clods (i.e. Times 1 and 2; Fig. 6). This caused a significant interaction between position and time of sampling $(3,56 \mathrm{df}, F=2.80, \mathrm{p}<$ $0.05)$ specifically because, for the first 2 samples, clods far from the seafloor lost more weight than those closer to the seafloor (Fig. 6). Thus, the physical environment with respect to water flow and sediment scour was pos- 
(a) coarse

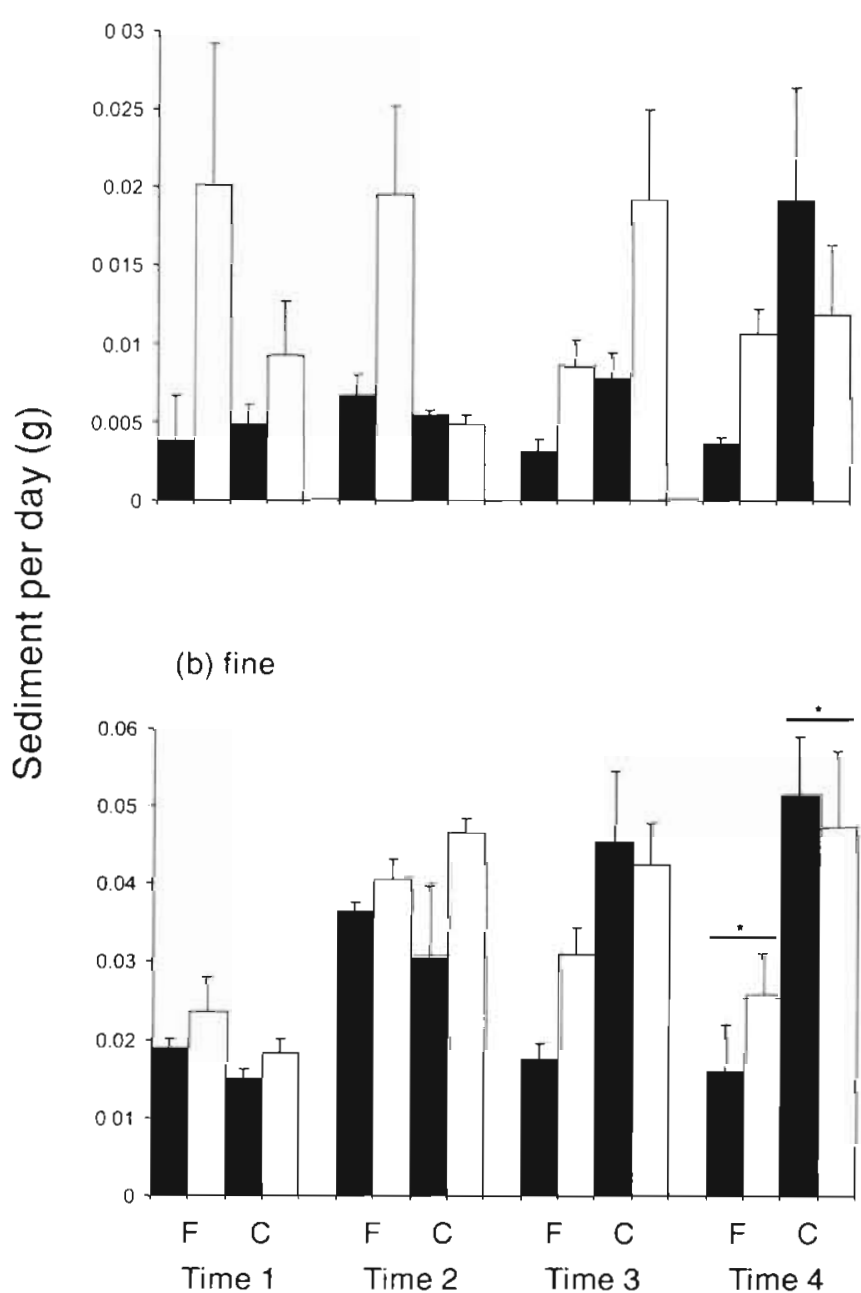

Fig. 5. Grams (+ SE) of (a) coarse and (b) fine sediment collected per day in sediment traps with $(\mathbb{\square})$ and without $(\square)$ roofs in positions far from (F) and close to (C) the seafloor Significant differences indicated as in Fig. 4

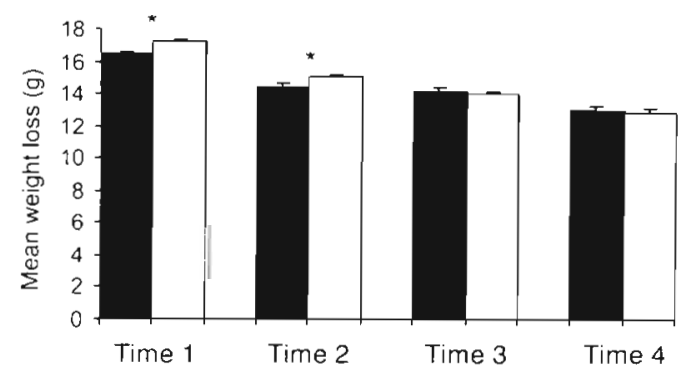

Fig. 6. Weight loss (+ SE) of plaster clods positioned far from the seafloor ( $\square$ ) and close to the seafloor ( $\square$ ) over $3 \mathrm{~d}$ measured on 4 separate occasions. Asterisks indicate significant differences between positions sibly slightly different in the 2 positions, but this difference was by no means constant and could have been most prominent when mean water/sediment movement was greatest. This method did not allow any differentiation between effects of water flow and sediment scour as they both influence the loss of weight from plaster clods.

\section{DISCUSSION}

This experiment demonstrated that shading and proximity to the seafloor can both greatly influence the development of subtidal epibiotic assemblages in estuaries. Furthermore, the effect of shading appeared to differ according to proximity to the seafloor and effects of both factors differed between times of sampling (possibly as a consequence of the assemblages becoming more developed). Assemblages far from the seafloor were less affected by shade at the second time of sampling, although, at both times, shading influenced the cover of some taxa.

Assemblages that developed on shaded plates far from the seafloor were, qualitatively, more similar to assemblages sampled previously on shaded pier pilings (Glasby 1999a) than were assemblages that developed on shaded plates positioned close to the seafloor. Conversely, assemblages on unshaded plates close to the seafloor were, qualitatively, very similar to those described previously on rocky reefs (Glasby 1999a). Shaded plates far from the seafloor were characterized (like pilings) by Hydroides spp., encrusting bryozoans (Schizoporella errata and Watersipora subtorquata), sponges and, to a lesser extent, solitary and colonial ascidians. Unshaded plates, close to the seafloor were characterized (like rocky reefs) by spirorbids, ceramialean algae, Oscillatoria sp. and brown filamentous algae. These results strongly support the model that the interactive effects of shading and proximity to the seafloor explain differences between assemblages on pilings and rocks better than either factor on its own.

It is not clear why assemblages close to the seafloor should be so different from those positioned a few metres from the seafloor. It was impossible to totally unconfound proximity to the shore-plates that were close to the seafloor were also $6 \mathrm{~m}$ closer to the shore than plates far from the seafloor. Both treatments were, however, greater than $20 \mathrm{~m}$ from the shore and it is considered unlikely that the slight difference in proximity to the shore was responsible for the large differences between assemblages close to and far from the seafloor. There is also the question of why the effect of shading was less marked in positions far from the seafloor after $33 \mathrm{wk}$ (Fig. 2, Table 2b). It is possible that the difference in light intensity between shaded treat- 
ments in the 2 positions may have been enough to cause some of the differences between these assemblages. So, the less distinct effect of shading on assemblages far from the seafloor may have been an artefact due to light levels being reduced less effectively in these positions. Certainly, however, the large differences between unshaded assemblages in the 2 positions were unlikely to have been related to differences in light levels (see Fig. 1).

It is questionable whether sedimentation may have any significant effect on assemblages growing on vertical surfaces. Nevertheless, in the present study, there was the potential for rates of sedimentation to differ between treatments with and without roofs. As it turned out, assemblages on plates with and without roofs were not significantly different, so comparisons of rates of sedimentation between these treatments were irrelevant. There were, however, differences between assemblages close to and far from the seafloor and corresponding differences in sedimentation. Specifically, more fine sediment was collected in positions close to than far from the seafloor on 2 sampling occasions, a result consistent with other studies (e.g. Airoldi et al. 1996). This difference in sedimentation could possibly explain some of the differences between assemblages in the 2 positions. Certainly, many of the taxa that differed in abundance between plates close to and far from the seafloor were filter-feeders (e.g. polychaetes, barnacles, bryozoans, sponges) and their feeding (and therefore growth/survival) may have been influenced either positively or negatively by the quantity of fine sediment in the water column. Many of the data available on effects of sedimentation on these taxa (Moore 1977) are, in general, consistent with the patterns of the present study, but there is certainly great variability among species in responses to sedimentation. A great deal more work is needed to test whether the types of differences in sedimentation described here could explain any of the observed differences in epibiotic assemblages.

There were no obvious differences in the physical environment with respect to water flow and scouring between positions close to and far from the seafloor, except perhaps a tendency for differences to occur when mean water/sediment movement was greatest (Fig. 6). The clod card technique used here did not allow water flow and sediment scouring to be discriminated and it is possible that the relative importances of the two were quite different close to and far from the seafloor. Scouring by sediments can potentially influence abundances of sessile biota (Moore 1977. Kendrick 1991) and could have contributed to differences between assemblages close to and far from the seafloor. Water movement at the smallest spatial scales was unlikely to be different between the 2 positions because identical settlement plates and supporting structures were used in each. Structures close to the seafloor were not, however, attached to pilings and so could have had slightly different water flow around them. Water flow at meso-scales may have been influenced by proximity to the bottom which could, in turn, affect the settlement of larvae (e.g. Breitberg et al. 1995, Guichard \& Bourget 1998) and possibly the distribution of larvae or propagules in the water column. Similarly, the behaviour of larvae could help explain different abundances of epifauna with proximity to the seafloor (e.g. polychaetes; Smith 1984, Scheltema 1986). Sampling the distribution of larvae and propagules in the water column would help elucidate whether this could contribute to some of the observed patterns in epibiotic assemblages.

Predation is often cited as being responsible for differences in abundances of sessile organisms. Invertebrate grazers can have large effects on abundances of subtidal epibiota (Ayling 1981, Young \& Chia 1984, Breitberg 1985, Sebens 1985, 1986, Davis 1988, Osman et al. 1992). Sampling in the present study was not designed to estimate abundances of mobile species, so it is not known whether small grazers were present on plates. The crab Plagusia chabrus (which feeds on sessile invertebrates) was, however, observed frequently on pilings (i.e. where plates were attached far from the seafloor). Breitberg (1985) described epibiotic assemblages developing on plates that were exposed to predation (primarily grazing by sea stars and urchins) as being dominated by algae (i.e. similar to assemblages close to the seafloor in the present study), whereas plates protected from grazers had a greater cover of sessile animals (i.e. similar to assemblages far from the seafloor in the present study). Two sea stars, the oreasterid Anthenea sidneyensis and the astropectinid Astropecten polyacanthus, were common at the study site and the former was observed occasionally on settlement plates close to the seafloor. A. polyacanthus and other species in this family typically feed on molluscs in soft sediments, but oreasterid sea stars are generally omnivorous and may feed on epibiota (Jangoux 1982).

Fishes can also affect distributions and abundances of subtidal epibiota (Russ 1980, Ayling 1981, Keough \& Downes 1982, 1986, Keough 1984, Breitberg 1985 , Stoner 1990). Various species of monacanthids, labrids, scarids, mullids and syngnathids were seen feeding from plates in the present study. Octopuses were also common at the study site and were, together with labrids and mullids, observed only near plates positioned close to the seafloor. Thus, differential predation by fishes and/or invertebrates could potentially explain some of the differences between assemblages in the 2 positions. Moreover, the effects of predation 
may interact with degree of shading because the distribution of some mobile predators can be influenced by shade (e.g. fishes; Hair et al. 1994). Certainly there are numerous models which could explain why proximity to the seafloor may significantly influence the development of subtidal epibiotic assemblages. Differences in predation, water flow and sedimentation/scouring were considered likely in the present study, but it is necessary to test each of these using manipulative experiments before their roles can be evaluated.

Many studies have demonstrated that shading can influence the distributions and abundances of epibiota (e.g. Reed \& Foster 1984, Kennelly 1989, Duggins et al. 1990, Glasby 1999b), but few have identified the importance of proximity to the seafloor and none has examined the interactive effects of the two. These 2 factors will, however, often be important to consider when comparing artificial and natural substrata. Furthermore, many studies of sessile epibiotic assemblages have utilized settlement plates attached to pilings or floating rafts (e.g. Wisely 1959, Osman 1977, Russ 1977, 1982, Sutherland \& Karlson 1977, Withers \& Thorp 1977, Dean \& Hurd 1980, Greene \& Schoener 1982, Todd \& Keough 1994). Thus, the plates are often shaded and positioned many metres from the seafloor (and also move if they are attached to rafts) and, consequently, the assemblages that develop on them are likely to be very different from those on natural hard substrata. This, in itself, is not a problem, indeed, most of our current knowledge about epibiota came from such studies on fouling organisms, but we need to consider just how different assemblages on artificial and natural surfaces may be. This is becoming even more necessary given the increasing urban development in harbours around the world and the associated addition of artificial structures to the marine environment.

Acknowledgements. This research was funded by the Centre for Research on Ecological Impacts of Coastal Cities (University of Sydney). Thanks to T. Davies, S. Heislers, D. Butters, P. Barnes, G. Housefield and M. Abbiati, who provided assistance in the field, and Dr L. Airoldi, who helped identify algae. The Royal Volunteer Coastal Patrol (Sydney) kindly allowed me to do work at their marina. Sandstone was provided by Gosford Quarries Pty Ltd. Versions of this manuscript benefited greatly from comments by Dr M. Lindegarth, DrM. J. Anderson, Prof. A. J. Underwood and anonymous referees.

\section{LITERATURE CITED}

Airoldi L, Cinelli F (1997) Effects of sedimentation on subtidal macroalgal assemblages: an experimental study from a Mediterranean rocky shore. J Exp Mar Biol Ecol 215: $269-288$

Airoldi L, Fabiano M, Cinelli F (1996) Sediment deposition and movement over a turf assemblage in a shallow rocky coastal area of the Ligurian Sea. Mar Ecol Prog Ser 133: 241-251

Anderson MJ, Underwood AJ (1994) Effects of substratum on the recruitment and development of an intertidal estuarine fouling assemblage. J Exp Mar Biol Ecol 184:217-236

Ayling AM (1981) The role of biological disturbance in temperate subtidal encrusting communities. Ecology 62: 830-847

Breitburg DL (1985) Development of a subtidal epibenthic community: factors affecting species composition and the mechanisms of succession. Oecologia 65:173-184

Breitberg DL, Palmer MA, Loher T (1995) Larval distributions and the spatial patterns of settlement of an oyster reef fish: responses to flow and structure. Mar Ecol Prog Ser 125: $45-60$

Butler AJ (1986) Recruitment of sessile invertebrates at five sites in Gulf St. Vincent, South Australia. J Exp Mar Biol Ecol 97:13-36

Butler AJ (1991) Effect of patch size on communities of sessile invertebrates in Gulf St. Vincent, South Australia. J Exp Mar Biol Ecol 153:255-280

Butler AJ, Connolly RM (1996) Development and long term dynamics of a fouling assemblage of sessile marine invertebrates. Biofouling 9:187-209

Caffey HM (1982) No effect of naturally-occurring rock types on settlement or survival in the intertidal barnacle Tesseropora rosea (Krauss). J Exp Mar Biol Ecol 63:119-132

Clarke KR, Green RH (1988) Statistical design and analysis for a 'biological effects' study. Mar Ecol Prog Ser 46: $213-226$

Connell SD, Glasby TM (1999) Do urban structures influence local abundance and diversity of subtidal epibiotd? A case study from Sydney Harbour, Australia. Mar Environ Res 47:373-387

Crisp DJ, Ryland JS (1960) Influence of filming and of surface texture on the settlement of marine organisms. Nature 185:119

Davis AR (1988) Colony regeneration following damage and size-dependent mortality in the Australian ascidian Podoclavella moluccensis Sluiter. J Exp Mar Biol Ecol 123: 269-285

Dean TA, Hurd LE (1980) Development in an estuarine fouling community: the influence of early colonists on later arrivals. Oecologia 46:295-301

Doty MS (1971) Measurement of water movement in reference to benthic algal growth. Bot Mar 14:32-35

Duggins DO, Eckman JE, Sewell AT (1990) Ecology of understory kelp environments. II. Effects of kelps on recruitment of benthic invertebrates. J Exp Mar Biol Ecol 143:27-45

Fuller JL (1946) Season of attachment and growth of sedentary marine organisms at Lamoine, Maine. Ecology 27: $150-158$

Glasby TM (1998) Estimating spatial variability in developing assemblages of epibiota on subtidal hard substrata. Mar Freshw Res 49:429-437

Glasby TM (1999a) Differences between subtidal epibiota on pier pilings and rocky reefs at marinas in Sydney, Australia. Estuar Coast Shelf Sci 48:281-290

Glasby TM (1999b) Effects of shading on subtidal epibiotic assemblages. J Exp Mar Biol Ecol 234:275-290

Glasby TM, Connell SD (1999) Urban structures as marine habitats. Ambio 28:595-598

Greene $\mathrm{CH}$, Schoener A (1982) Succession on marine hard substrata: a fixed lottery. Oecologia 55:289-297

Guichard F, Bourget E (1998) Topographic heterogeneity, hydrodynamics, and benthic community structure: a scale-dependent cascade. Mar Ecol Prog Ser 171:59-70 
Hair CA, Bell JD, Kingsford MJ (1994) Effects of position in the water column, vertical movement and shade on settlement of fish to artificial habitats. Bull Mar Sci 55:434-444

Harlin MM, Lindbergh JM (1977) Selection of substrata by seaweeds: optimal surface relief. Mar Biol 40:33-40

Jangoux $M$ (1982) Food and feeding mechanisms: Asteroidea. In: Jangoux M, Lawrence JM (eds) Echinoderm nutrition. AA Balkema, Rotterdam, p 117-159

Jokiel PL, Morrissey JI (1993) Water motion on coral reefs: evaluation of the 'clod card' technique. Mar Ecol Prog Ser 93:175-181

Karlson R (1978) Predation and space utlization patterns in a marine epifaunal community. J Exp Mar Biol Ecol 31: $225-239$

Kay AM, Butler AJ (1983) 'Stability' of the fouling communities on the pilings of two piers in South Australia. Oecologia 56:70-78

Kay AM, Keough MJ (1981) Occupation of patches in the epifaunal communities on pier pilings and the bivalve Pinna bicolour at Edithburgh, South Australia. Oecologia 48 $123-130$

Kendrick GA (1991) Recruitment of coralline crusts and filamentous turf algae in the Galapagos archipelago: effect of simulated scour, erosion and accretion. J Exp Mar Biol Ecol 147:47-63

Kennelly SJ (1989) Effects of kelp canopies on understorey species due to shade and scour. J Exp Mar Biol Ecol 50 . $215-224$

Keough MJ (1984) Dynamics of the epifauna of the bivalve Pinna bicolor: interactions among recruitment, predation and competition. Ecology 65:677-688

Keough MJ, Downes BJ (1982) Recruitment of marine invertebrates: the role of active larval choices and early mortality. Oecologia 54:348-352

Keough MJ, Downes BJ (1986) Effects of settlement and postsettlement mortality on the distribution of the ascidian $T r i-$ didemnum opacum. Mar Ecol Prog Ser 33:279-285

Long ER, Rucker JB (1970) Offshore marine cheilostome bryozoa from Fort Lauderdale, Florida. Mar Biol 6:18-25

McGuinness KA (1989) Effects of some natural and artificial substrata on sessile marine organisms at Goleta Reef, Panama. Mar Ecol Prog Ser 52:201-208

Moore PG (1977) Inorganic particulate suspensions in the sea and their effects on marine animals. Oceanogr Mar Biol Annu Rev 15:225-363

Osman RW (1977) The establishment and development of a marine epifaunal community. Ecol Monogr 47:37-63

Osman RW, Whitlatch RB, Malatesta RJ (1992) Potential role of micro-predators in determining recruitment into a marine benthic community. Mar Ecol Prog Ser 83:35-43

Pomerat CM, Weiss CM (1946) The influence of texture and composition of surface on the attachment of sedentary

Editorial responsibility: Otto Kinne (Editor),

Oldendorf/Luhe, Germany marine organisms. Biol Bull Mar Biol Lab (Woods Hole) 91 $57-65$

Reed DC, Foster MS (1984) The effects of canopy shading on algal recruitment and growth in a giant kelp forest. Ecology 65:937-948

Russ GR (1977) A comparison of the marine fouling occurring at the two principal Australian naval dockyards. Department of Defence, Australia, Melbourne

Russ GR (1980) Effects of predation by fishes, competition, and the structural complexity of the substratum on the establishment of a marine epifaunal community. J Exp Mar Biol Ecol 42:55-69

Russ GR (1982) Overgrowth in a marine epifaunal community: competitive hierarchies and competitive networks. Oecologia 53:12-19

Scheltema RS (1986) On dispersal and planktonic larvae of benthic invertebrates: an eclectic overview and summary of problems. Bull Mar Sci 39:290-322

Sebens KP (1985) Community ecology of vertical rock walls in the Gulf of Maine, U.S.A.: small-scale processes and alternative community states. In: Moore PG, Seed R (eds) The ecology of rocky coasts. Hodder \& Stoughton, London, p 346-371

Sebens KP (1986) Spatial relationships among encrusting marine organisms in the New England subtidal zone. Ecol Monogr 56:73-96

Smith R (1984) Development and settling of Spirobranchus giganteus (Polychaeta; Serpulidae). In: Hutchings PA (ed) Proceedings of the First International Polychaete Conference, Sydney. The Linnean Society of New South Wales, Sydney, p 461-483

Stoner DS (1990) Recruitment of a tropical colonial ascidian: relative importance of pre-settlement vs. post-settlement processes. Ecology 71:1682-1690

Sutherland JP, Karlson RH (1977) Development and stability of the fouling community at Beaufort, North Carolina. Ecol Monogr 47:425-446

Todd CD, Keough MJ (1994) Larval settlement in hard substratum epifaunal assemblages: a manipulative field study of the effects of substratum filming and the presence of incumbents. J Exp Mar Biol Ecol 181:159-187

Wisely B (1959) Factors influencing the settling of the principal marine fouling organisms in Sydney Harbour Aust $J$ Mar Freshw Res 10:30-44

Withers RG. Thorp CH (1977) Studies on the shallow, sublittoral epibenthos of Langstone Harbour, Hampshire, using settlement panels. In: Keegan BF, Ceidigh PO, Boaden PJS (eds) Biology of benthic organisms. Pergamon Press, London, p 595-604

Young CM, Chia FS (1984) Microhabitat-associated variability in survival and growth of subtidal solitary ascidians during the first 21 days after settlement. Mar Biol 81:61-68

Submitted: April 26, 1999; Accepted: August 2, 1999

Proofs received from author(s): November 19, 1999 